\title{
Molt-Related and Size-Dependent Differences in the Escape Response and Post-Threat Behavior of the American Lobster, Homarus americanus
}

\author{
S. I. CROMARTY,* J. MELLO, AND G. KASS-SIMON $\dagger$ \\ Biological Sciences Department, University of Rhode Island, Kingston, Rhode Island 02881
}

\begin{abstract}
Videotaped recordings of adult lobsters of different molt stages were analyzed. The escape response of adults was compared with that of juveniles recorded in an earlier study.

Juvenile lobsters always respond to a threat with escape behavior irrespective of their molt stage, but in adults the probability of eliciting a response was a function of molt stage: more hard-shelled (intermolt stage C) and (premolt stage D) animals tailflipped than did soft-shelled (postmolt stages $\mathrm{A}$ and $\mathrm{B}$ ) animals.

The number, frequency, and duration of tailflips, and the average distance swum by animals in each molt stage were measured for the entire escape response, for the initial power swim, and for the subsequent swims. These measurements were used to compute several parameters: velocity, acceleration, force, and work; average distance traveled in a tailflip for each kilogram of body weight (distance $/ \mathrm{kg} / \mathrm{tail}$ flip); and average distance traveled for each bodylength (distance/bodylength).
\end{abstract}

Among adults, intermolt (stage C) lobsters traveled significantly farther and faster than postmolt animals (stages A and B). Among juveniles, late postmolt (stage B) animals traveled farther. Among adults, although the total number of tailflips and the duration of the response were not significantly different among molt stages, the number of tailflips/ second (frequency) and distance traveled $/ \mathrm{kg} /$ tailflip were greater for intermolt animals. In juvenile intermolts, however, frequency and distance/ $\mathrm{kg} /$ tailflip were markedly

Received 22 October 1999; accepted 7 July 2000

* Present address: Department of Natural Sciences, Assumption College, 500 Salisbury Street, Worcester, MA 01609-1296. E-mail: scromart@eve.assumption.edu

† To whom correspondence should be addressed. Biological Sciences Department, University of Rhode Island, 100 Flagg Rd., Kingston, RI 02881-0816. E-mail: Kass.Simon@uri.edu lower than in the premolt stages. Although values were lower than intermolts and premolts, postmolt adults sustained their swimming frequency, distance $/ \mathrm{kg} /$ tailflip, and distance/bodylength for the entire escape distance (as did postmolt juveniles). These parameters then dropped off sharply for both adult and juvenile intermolt and premolt animals in the second half of the escape distance.

Post-threat behaviors reveal that stage D animals have the highest aggression index and often attack the presented stimulus, whereas stage A animals are the least likely to approach the stimulus and typically back away in a nonaggressive posture.

Thus, although effects of the molt cycle on adult and juvenile escape behavior are similar in some ways, other physical characteristics of adults, such as weight, allometry, and physiology, seem to become important in determining the likelihood of escape behavior and the characteristics of the escape swim in each molt stage.

\section{Introduction}

The behavior of the American lobster, Homarus americanus, varies (both in the laboratory and in the field) with sex and reproductive state (Cowan and Atema, 1990; Figler et al., 1997, 1998; Cromarty et al., 1998; Mello et al., 1999), relative size (Scrivener, 1971; Lang et al., 1977), time in residence (O'Neill and Cobb, 1979; Peeke et al., 1998; Cromarty et al., 1999), and dominance (Karnofsky and Price, 1989; Huber and Kravitz, 1995). However, moltcycle-related behaviors have been rarely been studiedprobably because the long-term approaches and experimental designs needed are complex.

The physiological transformations that occur in decapod crustaceans over the molt cycle are clearly profound; they include a variety of metabolic, neuroendocrine, and neuro- 
physiological changes (Knowles and Carlisle, 1956; Passano, 1960; Kleinholz and Keller, 1979; Quackenbush, 1986) that could manifest themselves in distinctive moltstage-related behavioral modifications. Specifically, the escape response behavior in decapod crustaceans is ideally suited for modulation because it is composed of multiple tailflips, or swims. The escape response consists of an initial power swim followed by a series of subsequent swims; in crayfish, the initial power swim is elicited by visual and tactile excitation in the front of the animal which is mediated by the medial giant neuronal system, while tactile excitation of the telson at the rear of the animal is mediated by the lateral giant system. The subsequent swims immediately following the power swim are mediated by the nongiant system, which innervates the phasic flexor abdominal musculature (Wine and Krasne, 1972, 1982). Although the physiology of tailflip escape circuits has not yet been fully described in lobsters, the close similarity between the two species suggests that the innervation is similar.

While studying confrontations between juvenile American lobsters, Tamm and Cobb (1978) identified an increased probability of eliciting an escape response in early postmolt stages (stages A and B). In contrast, the frequency of aggressive behaviors, in particular the meral spread, increased during mid-premolt stages (stages $\mathrm{D}_{1}$ and $\mathrm{D}_{2}$ ). Hard-shelled lobsters tend to be aggressive, but soft-shelled lobsters tend to avoid confrontations. Stomatopods exhibit similar behavioral differences (Steger and Caldwell, 1983). These differences are understandable in view of the fact that in their postmolt, soft-shelled state, these animals are much more vulnerable to predation by predators and conspecifics than are hard-shelled animals, and they are less able to fend off attacks with aggressive behaviors, so that when threatened, they are forced to try to escape instead of mounting a defense (Tamm and Cobb, 1978; Atema and Cobb, 1980; Atema and Voigt, 1995).

One might expect that a newly molted animal would have difficulty doing much of anything until the exoskeleton hardens. Although this is true for lobsters in very early stage A, our studies revealed subtle differences in escape behavior among juvenile lobsters over the molt cycle (Cromarty et al., 1991; Cromarty, 1995). We found that overall, postmolt lobsters produced the more effective escape behavior. Softshelled, postmolt juvenile lobsters (stage B) traveled farther, produced more tailflips, and swam longer, at sustained velocity, than did premolt lobsters. Earliest postmolt (stage A) juveniles swam at a higher frequency. In contrast, premolt juveniles produced a quick, forceful initial power swim, followed by subsequent swims that rapidly decreased in velocity, acceleration, force, and work output (Cromarty et al., 1991).

The above studies focused on juvenile lobsters; even less information exists on molt-related changes in escape behavior in adult or larger animals. We know that the escape response occurs more frequently among juveniles and smaller adults than among large adults (Lang et al., 1977), and that the conduction time of medial giant impulses from the brain to the sixth abdominal ganglion increases greatly, causing an increase in the latency of the response. The relative ratio of abdomen length to carapace length decreases with increased size, forcing the abdominal flexing muscles to propel a larger body mass (mostly claws). As with crayfish (Krasne and Wine, 1975), removal of the claws of a large lobster increases its propensity to tailflip (Lang et al., 1977), as we have also observed in these experiments. Since large lobsters are less apt to be preyed upon than small ones (Atema and Voigt, 1995), it is expected that large soft- and hard-shelled adult lobsters would exhibit different but unique escape behaviors from one another.

Because of the physical and behavioral differences between adults and juveniles, on the one hand, and the physiological and behavioral differences among animals of different molt stages, on the other, we wished to investigate whether adults and juveniles in the same molt stage differed in the measurable characteristics of the escape response. We therefore examined the escape response of adult male lobsters of different molt stages in an experiment similar to the one we had designed for juvenile lobsters (Cromarty et al., 1991). We measured distance traveled (m); number of tailflips (Tf); duration of the response (s); frequency of tailflips $(\mathrm{Tf} / \mathrm{s})$; velocity $(\mathrm{m} / \mathrm{s})$, acceleration $(\mathrm{m} / \mathrm{s} / \mathrm{s})$, force $(\mathrm{N} ; \mathrm{kg}$. $\mathrm{m} / \mathrm{s} / \mathrm{s}$ ) and work (J) of each tailflip; distance traveled in each tailflip for each unit of body weight $(\mathrm{m} / \mathrm{kg} / \mathrm{Tf})$; distance traveled in each tailflip for each unit of bodylength (distance/bodylength); and distance traveled in each tailflip for each unit of body weight $(\mathrm{m} / \mathrm{kg})$. In addition, we compared the escape thresholds of juveniles and adults.

Our earlier work indicated that lobsters could show significant differences in post-stimulus behaviors towards the threatening object, as well as in the characteristics of the escape behavior itself (Cromarty et al., 1999). Thus we also analyzed post-stimulus agonistic behaviors and now present evidence that these behaviors-like escape behavior- differ significantly from one molt stage to another: premolt lobsters are more likely than postmolt animals to attack a threatening stimulus, and postmolt animals are more likely to back away from a stimulus with no display of aggression.

\section{Materials and Methods}

Procedures and experimental protocols are essentially the same as those described elsewhere (Cromarty et al., 1991, 1998, 1999), but are summarized again here with relevant differences included. 
Animals

Adult American lobsters (carapace length 74 to $90 \mathrm{~mm}$ ) were obtained and housed as described previously (Cromarty et al., 1999). Twenty-four hours prior to an experiment, an animal was moved to the Kingston campus of the University of Rhode Island, where it was placed in a holding tank $\left(30 \mathrm{~cm}^{3}\right)$ and was not fed during this acclimation and experimental period. Isolation periods in the holding tank were identical for all experimental animals. The tank had its own air supply. To avoid possible sex-related effects, only males were used in this study. Ten lobsters from each molt stage (A, B, C, and D) were randomly selected as they entered the stage. Lobsters weighed (in grams) an average of $451.4 \pm 69.6$ (mean $\pm \mathrm{SD}$ ) and had an average carapace length (in millimeters) of $81.3 \pm 4.7$ (mean $\pm \mathrm{SD})$.

The experiments were performed randomly so that no molt-stage clustering occurred. A correlation statistic was run to check for molt stage and date of experiment. No correlation was found between the animals' molt stage, the time between the animals' capture and their use in the experiment, and the sequence of experiments $\left(R^{2}<0.18\right.$, $F>0.05)$.

Lobsters were presented with the stimulus only once and were immediately sacrificed for identification of possible molt-related differences in the phasic flexor musculature system that is responsible for the escape response behavior. This required that over 200 animals be individually housed so that lobsters entering different molt stages could be selected.

Freshly caught lobsters were continually added to the holding population to reduce "inactivity" and potential for increasing aggressive behavior (Cromarty et al., 1999). Because of possible seasonal differences in physiology and morphology such as those described in crayfish (Lnenicka and Zhao, 1991), experiments were conducted between June and October when Rhode Island waters maintain temperatures between $18^{\circ} \mathrm{C}$ and $23^{\circ} \mathrm{C}$ and similar conditions can be maintained in the indoor holding tanks. Again, no correlation was found between any of the significant parameters and the date of experiment.

\section{Experiments}

Each experiment was run between 1200 and 1500 hours in a 4000-1 tank filled with filtered recirculated seawater. The large amount of seawater held in the experimental tank made it impractical to drain the tank after each experiment, but carbon filters were continuously used throughout this experimental period to remove possible recognition odors originating from the lobsters' urine. Nevertheless, a correlation statistic was run to check for success of tailflipping and lobster order. No correlation was found between the order of experiments and the animals' success and failure of tailflipping $\left(R^{2}<0.13, F>0.05\right)$.

Salinity was kept between $29 \%$ and $33 \%$, and adjustments (if any) were made before each experiment. One hour before an experiment, the physical condition of each animal was checked. Animals were used only if they moved around the tank or exhibited antennule flicking.

Water temperature in the experimental tank was maintained between $18^{\circ} \mathrm{C}$ and $20^{\circ} \mathrm{C}$ by a chiller. The experimental area consisted of an open-ended tank (1.0-m L $\times 0.3-\mathrm{m}$ $\mathrm{W} \times 0.3-\mathrm{m} \mathrm{H})$ immersed in a larger main tank $(2.2-\mathrm{m} \mathrm{L} \times$ $0.75-\mathrm{m} \mathrm{W} \times 0.91-\mathrm{m} \mathrm{H})$. A weighted wooden partition with a pulley acted as a blind (and separation to the main tank) at the open side of the experimental tank (Fig. 1A).

The experimental tank was designed with an open end so that a threatening stimulus could be introduced at that end. To ensure that lobsters were initially at the closed, nonstimulus end, a light was placed at the open end of the tank. The partition was raised once the lobster had reached the closed end. The light was then placed over the closed, non-stimulus end. This served to "push" the animal back towards the open (stimulus) end. Because adult lobsters did not respond to the stimulus that was used to induce an escape response in juveniles (a flat shiny and reflective mirror, $0.1 \mathrm{~m}^{2}$, housed in a wooden frame attached to a dowel stick), a piece of PVC tubing $(15-\mathrm{cm} \mathrm{L} \times 10-\mathrm{cm} \mathrm{W})$ weighted with pebbles weighing $1.45 \mathrm{~kg}$ served as the threatening stimulus. The stimulus was raised above the open end, as depicted in Figure 1A, and was released into the water at a preset distance of $10 \mathrm{~cm}$ (measured from the open edge of the tank to the lobster's rostrum) whenever a lobster approached the open end of the tank.

Cameras were placed in horizontal and vertical positions so that the experiments were simultaneously recorded on two video recording systems. Video recordings of each lobster were analyzed frame-by-frame. To measure distance traveled, a metric grid divided into $0.5-\mathrm{cm}$ units was painted onto the side of the experimental tank. Distance traveled along the length of the tank was measured using the position of the tip of the lobster's rostrum as the point of reference. Time was automatically recorded on the videotape, and numbers of tailflips were counted in subsequent viewing of the recordings.

After each experiment, the animal's molt stage was determined by examining cuticular and setal development in the pleopods (Aiken, 1973). Because animals become progressively harder after ecdysis (stage E), we also determined postmolt periods by testing various carapace areas for rigidity (Aiken, 1980). Experimental animals were placed in the following categories: intermolt (stage $\mathrm{C}$ ); premolt (stages $D_{0}, D_{1}, D_{2}$, or $D_{3}$ ); and postmolt (stage $A$ up to $48 \mathrm{~h}$ following ecdysis and stage B from 48 to $96 \mathrm{~h}$ after ecdysis).

Probabilities of an escape response were determined for each molt stage $(n=10)$ and statistically compared. The 
A

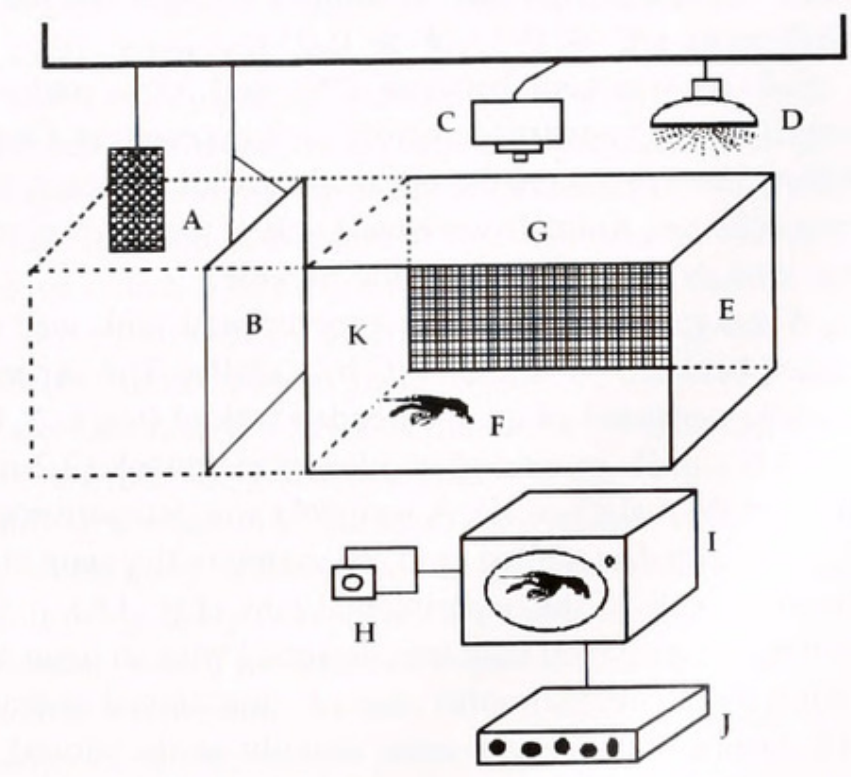

B

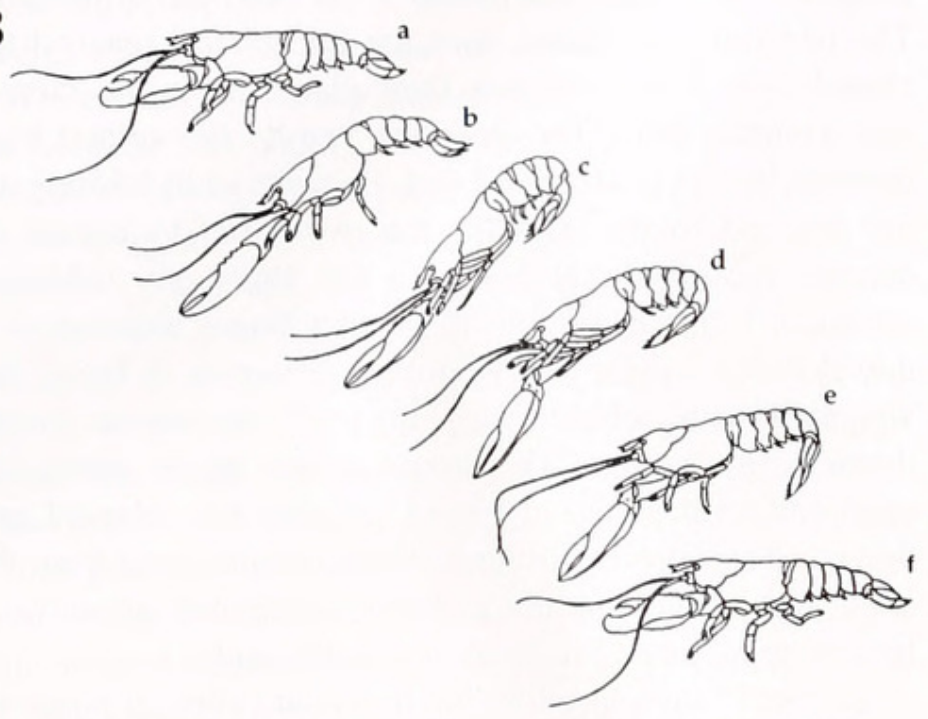

Figure 1. (A) Diagram of the experimental tank (E). The stimulus was a weighted piece of PVC tubing filled with pebbles (A); the screen (B) was lifted while the lobster $(\mathrm{F})$ was at the opposite end of the tank. A light (D) at the closed end of the tank caused the animal to move towards the darker open end $(\mathrm{K})$. The escape behavior of each lobster was recorded against a $0.5-\mathrm{cm}$ metrically divided grid $(\mathrm{G})$. The recording system consisted of vertical $(\mathrm{C})$ and horizontal $(\mathrm{H})$ cameras, a monitor $(\mathrm{I})$, and a time-lapse VCR (J). (B) Schematic breakdown of a single tailflip as it was seen in the video analysis: (a) = beginning of swim; $(f)=$ end of a single tailflip. (Drawings by K. Davignon, Graphics specialist, URI.) Previously published in The Biological Bulletin (Cromarty et al., 1998).

other characteristics of the escape response of animals that escaped were analyzed as in our earlier study of juvenile escape behavior (Cromarty et al., 1991, 1998, 1999).

\section{Videotape analysis}

Each of the escape parameters was analyzed for (1) the entire escape response; (2) the initial power swim; (3) the subsequent swims over the entire subsequent swimming distance; and (4) the subsequent swims in each half of that distance, since earlier experiments showed that there were differences in the total subsequent swimming distance traveled by lobsters. We therefore divided the distance traveled in the subsequent swims by half and analyzed each half (Cromarty et al., 1991, 1998, 1999). Because the distances differed and because each distance was divided equally in half for each escape sequence for each animal, no data are available to compare distance traveled between the two halves of the subsequent swims for each molt stage. (A complete tailflip, or swim, is defined as beginning immediately after the start of abdominal flexion and ending at abdominal extension [Fig. 1B: sequence a through f].) The following characteristics of the escape response were analyzed for each lobster: distance traveled (m), number of tailflips (Tf), duration of the response (s), frequency of tailflips $(\mathrm{Tf} / \mathrm{s})$, velocity $(\mathrm{m} / \mathrm{s})$, acceleration $(\mathrm{m} / \mathrm{s} /$ $\mathrm{s})$, force $[\mathrm{N} ;(\mathrm{kg} \cdot \mathrm{m} / \mathrm{s} / \mathrm{s})]$, work $(\mathrm{J})$, distance traveled/weight/ tailflip $(\mathrm{m} / \mathrm{kg} / \mathrm{Tf})$, distance traveled $/$ weight $(\mathrm{m} / \mathrm{kg})$, and distance traveled/lobster bodylength. The latter two parameters were calculated to determine whether individual lobster variability in weight and size altered the relative significance of a parameter. Velocity, acceleration, force, and work are all initially calculated from the distance that the individual tailflipped divided by the length of time the animal spent tailflipping. Calculations were based on the distance measured on the video records for the total escape response, the power stroke, and the subsequent swims. Therefore, because of small differences in each measurement due to the finite resolution of the number of frames per second of the video camera, the added mean values of the power stroke and subsequent swims are slightly different from the mean values of the total escape response. (The analysis of the escape response is meant to reflect relative changes in lobster escape behavior and not kinematic relationships such as those investigated by other researchers [Batchelor, 1967; Daniel and Meyhöfer, 1989; Nauen and Shadwick 1999].)

To quantify the degree of "aggression" in the post-stimulus behavior of each animal, we ordered the behavior towards the stimulus and then subjectively ranked an animal's post-stimulus threat behavior on a scale of 0 to 6 (Cromarty et al., 1999):

$0=$ back away, never approach

$1=$ approach but remain more than one bodylength away

$2=$ approach within one bodylength

$3=$ approach, touch

$4=$ approach, touch, grasp

$5=$ approach, touch, grasp, and tug or pull

$6=$ approach, touch and grasp, tug or pull and, execute an offensive tailflip

\section{Statistical analysis}

Molt stage versus probability of escape: Fisher's exact probability tests (FEPs) were used to determine differences in probabilities of an escape response over the molt stages. Because of the small number of stage A and B lobsters (4 
out of our original sample of 20 animals) that tailflipped $(n=4)$, the two molt stages were collapsed into a single sample to represent postmolt, soft-shelled lobsters. Stage C animals were classified as intermolts, and stage D lobsters were classified as premolts.

Comparison of weight and carapace length versus molt stage: Weight and carapace length among the molt stages were compared in a one-way analysis of variance (ANOVA) with a post-hoc Scheffé test to compare means of the planned comparisons. Weights of animals that escaped within each molt stage were compared to those that did not in a Mann-Whitney $U$ test (MW).

Characteristics of the escape response: Linear regressions were performed on all escape parameters against weight to double-check weight influence. Due to a nonnormal distribution of data, Kruskal-Wallis tests (KWs) were used for all the escape parameters except for the comparison of the first and second halves of the subsequent swims, where a multiple analysis of variance (MANOVA) with a one-way repeated measures follow-up test was used to compare the two halves of the subsequent swims.

Post-threat behaviors: Post-threat behaviors were quantified according to the "aggression index" and were compared in a one-way analysis of variance (ANOVA) with a post-hoc Scheffé test used to compare means of the planned comparisons.

KWs, ANOVAs, MANOVAs, and Scheffé tests were run using the University of Rhode Island mainframe computer (IBM ES/9000) and SPSS 6.1 software (SPSS Inc., Chi- cago) for the Macintosh G3 computer. Values for all tests were considered significant at $P \leq 0.05$, while trends were considered at $(0.05 \leq P \leq 0.10)$.

\section{Results}

\section{Comparison of adult and juvenile escape probabilities}

The data are summarized in Figure 2. In contrast to our earlier studies on small juveniles ( $\pm 14 \mathrm{~g}$ ) in which $100 \%$ of the 36 juvenile lobsters tailflipped ( 9 in each of the four stages; Cromarty et al., 1991), none of the larger juvenile ( $\geq 150 \mathrm{~g}$ ) or adult ( $\geq 450 \mathrm{~g}$ ) lobsters responded to the stick stimulus, regardless of size class or molt stage (see Fig. 2). Various stimuli (water injection over the lobster, a larger conspecific lobster, a predator (tautog), and bubbles blown over the lobster) also failed to elicit an escape response. However, a $15-\mathrm{cm}$-long piece of PVC tubing weighted with pebbles, dropped suddenly from above as the lobster approached, caused both larger juvenile $( \pm 150 \mathrm{~g})$ and adult $( \pm 450 \mathrm{~g})$ lobsters to tailflip (Fig. 2). In the large-juvenile size class, 23 out of 34 tailflipped (stage A: 4 of 8; stage B: 1 of 8 ; stage C: 9 of 9 ; stage D: 9 of 9 ). In the large-adult size class, 15 out of 40 tailflipped (stage A: 2 of 10; stage B: 2 of 10; stage C: 5 of 10; stage D: 6 of 10) or $20 \%$ of soft-shelled (stages A and B) and $55 \%$ of hard-shelled lobsters (stages $\mathrm{C}$ and $\mathrm{D}$; FEP, $P=0.01$ ). When comparing the probability of eliciting an escape response for softshelled (stages A and B) versus hard-shelled (stages C and D) lobsters, soft-shelled postmolt lobsters were significantly

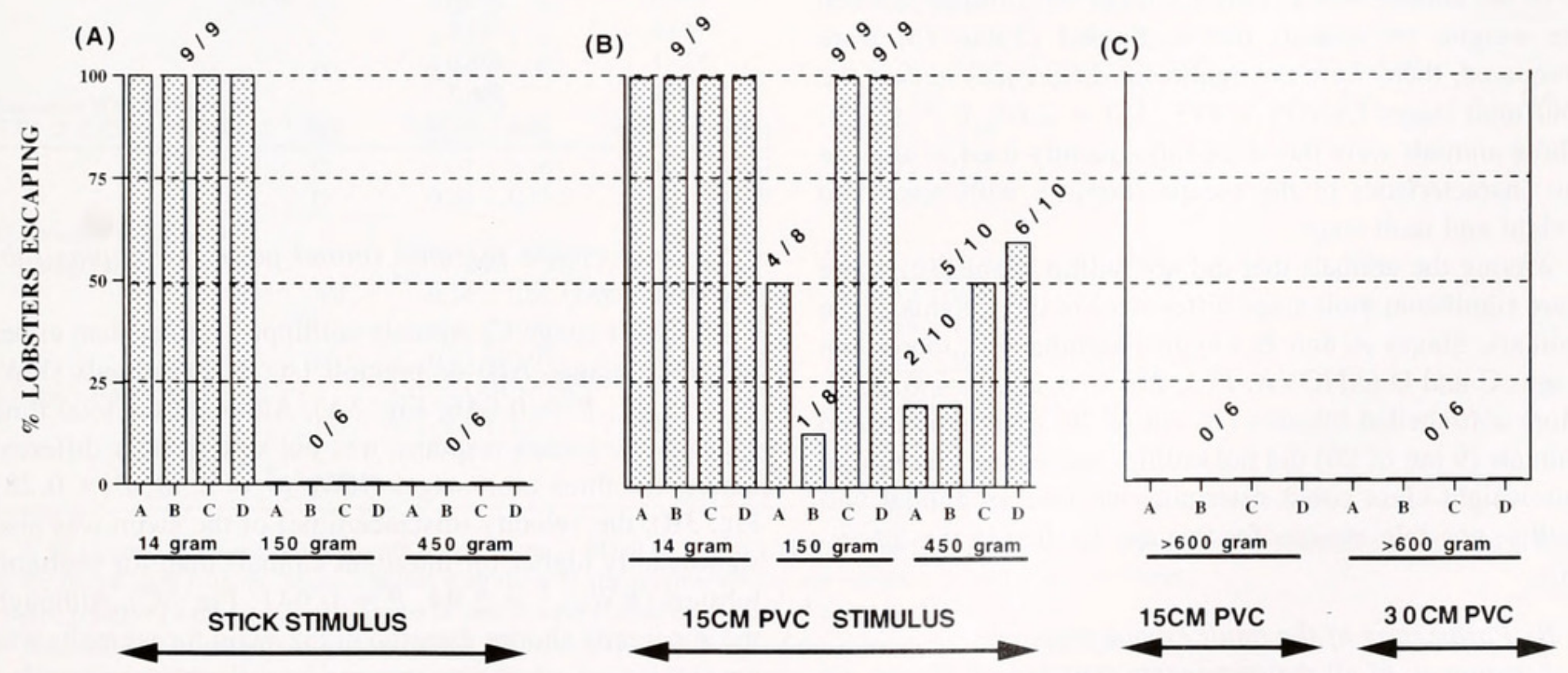

Figure 2. Percentage $(\%)$ of lobsters escaping at each weight and molt stage in response to stimuli of different sizes. The stimulus was (A) a stick to which a mirror was attached; (B) a $15-\mathrm{cm}$ length of PVC weighted with stone weighing $1.45 \mathrm{~kg}$; (C) two pieces of PVC tubing, one was $15 \mathrm{~cm}$ in length and weighing $1.45 \mathrm{~kg}$, and the other $30 \mathrm{~cm}$ in length and weighing $2.45 \mathrm{~kg}$ (animals heavier than $600 \mathrm{~g} \mathrm{did}$ not respond to the two stimuli). Molt stages, weights of animals, and types of stimuli are below the $x$-axis. Ratios at top of each bar are the number of lobsters escaping to the total number of animals presented with the stimulus. 
less likely to tailflip than hard-shelled premolt lobsters: $20 \%$ ( 4 of 20 ) compared to $55 \%$ ( 11 of 20) (FEP, $P=0.01$ ). Adult lobsters larger than $600 \mathrm{~g}$ did not tailflip, even when the size of the PVC tubing was increased from $15-\mathrm{cm} \mathrm{L} \times$ $10-\mathrm{cm} \mathrm{W}, 1.45 \mathrm{~kg}$, to $30-\mathrm{cm} \mathrm{L} \times 10-\mathrm{cm} \mathrm{W}, 2.45 \mathrm{~kg}$.

\section{Analysis of escape behavior in adults}

\section{A. Effect of weight on escape response in the various} molt stages

As had been shown by Lang et al. (1977), size and weight have significant effects on a lobster's propensity to exhibit an escape response.

Among the groups of animals tested, there were significant differences in weights (Table 1a). Stage B lobsters weighed significantly more than either stages $\mathrm{C}$ or $\mathrm{D}$ (ANOVA, $F(3,36)=7.42, P=0.0005)$. Stage B lobsters also had significantly larger carapace lengths than either stages $\mathrm{C}$ or D (ANOVA, $F(3,36)=15.69, P=$ 0.0001 ).

To determine whether any of the characteristics of the escape response were correlated with weight, linear regressions were calculated in which each of the following seven parameters were evaluated against weight, irrespective of molt stage: (1) probability of tailflipping; (2) duration of escape swimming; (3) tailflip frequency, (4) velocity, and (5) acceleration of the total escape swim; (6) force exerted during the swim; and (7) work performed. No correlation was found between the animals' weights and any of the parameters tested $\left(R^{2}<0.20 ; F>0.05\right)$.

Of the animals tested, only 15 out of 40 tailflipped. When the weights of animals that tailflipped (Table 1b) were compared, there were no significant differences among the four molt stages (ANOVA, $F(3,11)=2.61, P=0.11$ ). These animals were therefore subsequently used to analyze the characteristics of the escape response with respect to weight and molt stage.

Among the animals that did not tailflip (Table 1c), there were significant molt-stage differences in the weights of the animals. Stages A and B weighed significantly more than stages $\mathrm{C}$ and D (ANOVA, $F(3,21)=4.22, P=0.002)$. More soft-shelled lobsters (16 out of 20) than hard-shelled animals ( 9 out of 20) did not tailflip, suggesting that size in this weight class could determine whether an animal will tailflip; possible reasons for this are detailed in the discussion.

\section{B. Parameters of the adult escape response}

A summary of all the parameters tested, with means and standard deviations for each molt stage, are summarized in Table 2. Precision of measurements is a function of the number of video frames per second; therefore, since the power stroke and subsequent swims were separately analyzed, their mean values are not additive.

\section{Table 1}

Weight (in grams) for adult lobsters in the four molt stages; values are mean \pm standard error of the mean

\begin{tabular}{|c|c|c|c|}
\hline \multicolumn{2}{|c|}{ Softshelled premolt } & \multirow{2}{*}{$\begin{array}{c}\begin{array}{c}\text { Hardshelled } \\
\text { intermolt }\end{array} \\
\text { STAGE C }\end{array}$} & \multirow{2}{*}{$\begin{array}{c}\text { Premolt } \\
\text { STAGE D }\end{array}$} \\
\hline STAGE A & STAGE B & & \\
\hline \multicolumn{4}{|c|}{ (a) Combined weights of all lobsters irrespective of escape behavior } \\
\hline 514.3 & 595.1 & 420.3 & 372.1 \\
\hline 474.2 & 512.1 & 421.0 & 403.4 \\
\hline 470.0 & 582.0 & 373.0 & 440.2 \\
\hline 592.2 & 358.6 & 456.0 & 326.2 \\
\hline 401.0 & 544.2 & 435.6 & 424.5 \\
\hline 497.0 & 441.4 & 417.4 & 484.9 \\
\hline 400.0 & 487.6 & 438.7 & 396.0 \\
\hline 535.1 & 438.0 & 390.6 & 360.4 \\
\hline 476.2 & 513.4 & 433.5 & 378.0 \\
\hline 420.8 & 596.3 & 369.0 & 465.1 \\
\hline $478.1 \pm 19.3$ & $506.9 \pm 24.6$ & $415.5 \pm 9.2$ & $405.1 \pm 15.5$ \\
\hline \multicolumn{4}{|c|}{ (b) Animals that tailflipped } \\
\hline 470.0 & 441.4 & 420.3 & 403.4 \\
\hline 420.8 & 513.4 & 421.0 & 326.2 \\
\hline & & 456.0 & 484.9 \\
\hline & & 435.6 & 396.0 \\
\hline & & 438.7 & 360.4 \\
\hline & & & 378.0 \\
\hline $445.4 \pm 24.6$ & $477.4 \pm 36.0$ & $434.3 \pm 6.6$ & $391.5 \pm 21.8$ \\
\hline \multicolumn{4}{|c|}{ (c) Animals that did not escape } \\
\hline 514.3 & 595.1 & 373.0 & 372.1 \\
\hline 474.2 & 512.1 & 417.4 & 440.2 \\
\hline 592.2 & 358.6 & 390.6 & 424.5 \\
\hline 401.0 & 544.2 & 433.5 & 465.1 \\
\hline 497.0 & 582.0 & 369.0 & \\
\hline 400.0 & 487.6 & & \\
\hline 535.1 & 438.0 & & \\
\hline 476.2 & 596.3 & & \\
\hline $486.3 \pm 22.9$ & $514.2 \pm 29.7$ & $396.7 \pm 12.6$ & $425.5 \pm 19.7$ \\
\hline
\end{tabular}

1. Total escape response (initial power swim plus subsequent swims)

Intermolt (stage C) animals tailflipped farther than either postmolt (stages $\mathrm{AB}$ ) or premolt (stage $\mathrm{D}$ ) animals $(\mathrm{KW}$, $\chi^{2}=5.42, P=0.046$; Fig. 3A). Although the total time spent in the escape response was not significantly different among the three molt stages $\left(\mathrm{KW}, \chi^{2}=2.58, P=0.28\right.$; Fig. 3B), the velocity (distance/time) of the swim was also significantly higher for intermolt animals than for postmolt lobsters (KW, $\chi^{2}=5.94, P=0.041$; Fig. 3C). Although the apparently shorter duration of the swim for premolts was not significant, when time was used to calculate acceleration (velocity/time), the resulting value became significantly greater for premolt (stage D) lobsters $\left(\mathrm{KW}, \chi^{2}=6.76\right.$, $P=0.034$; Fig. 3D). Neither the force (weight $\times$ acceleration) exerted nor the work (force $\times$ distance) performed proved to be significantly different for the three molt stages 
Table 2

Summary of significant differences among all components analyzed over the escape response

\begin{tabular}{|c|c|c|c|c|c|c|c|}
\hline Component & $\begin{array}{l}\text { Molt } \\
\text { stage }\end{array}$ & $\begin{array}{l}\text { Total escape } \\
\text { response }\end{array}$ & $\begin{array}{l}\text { Initial power } \\
\text { swim }\end{array}$ & $\begin{array}{c}\text { Total } \\
\text { subsequent } \\
\text { swims }\end{array}$ & $\begin{array}{c}\text { Subsequent } \\
\text { swims } 1 \text { (SS1) }\end{array}$ & $\begin{array}{c}\text { Subsequent } \\
\text { swims } 2 \text { (SS2) }\end{array}$ & $\begin{array}{l}\text { SS1 vs. } \\
\text { SS2 }\end{array}$ \\
\hline \multirow[t]{4}{*}{ Distance $(\mathrm{m})$} & & $C>(A B=D)$ & $C>(A B=D)$ & $\mathrm{C}>(\mathrm{AB}=\mathrm{D})$ & NA & NA & NA \\
\hline & $\mathrm{AB}$ & $0.29 \pm 0.27$ & $0.06 \pm 0.01$ & $0.25 \pm 0.23$ & & & \\
\hline & $\mathrm{C}$ & $0.71 \pm 0.10$ & $0.17 \pm 0.02$ & $0.64 \pm 0.08$ & & & \\
\hline & $\mathrm{D}$ & $0.39 \pm 0.05$ & $0.08 \pm 0.02$ & $0.35 \pm 0.23$ & & & \\
\hline \multirow[t]{4}{*}{ Duration (s) } & & NS & NS & NS & NS & NS & NS \\
\hline & $\mathrm{AB}$ & $1.08 \pm 0.53$ & $0.29 \pm 0.23$ & $1.03 \pm 0.47$ & $0.35 \pm 0.24$ & $0.70 \pm 0.39$ & \\
\hline & $\mathrm{C}$ & $1.32 \pm 0.29$ & $0.13 \pm 0.04$ & $1.08 \pm 0.39$ & $0.38 \pm 0.10$ & $0.86 \pm 0.16$ & \\
\hline & $\mathrm{D}$ & $0.81 \pm 0.58$ & $0.21 \pm 0.13$ & $0.75 \pm 0.62$ & $0.29 \pm 0.25$ & $0.61 \pm 0.38$ & \\
\hline \multirow[t]{4}{*}{ Velocity $(\mathrm{m} / \mathrm{s})$} & & $\mathrm{C}>(\mathrm{AB}=\mathrm{D})$ & NS & NS & NS & NS & NS \\
\hline & $\mathrm{AB}$ & $0.28 \pm 0.22$ & $0.63 \pm 0.24$ & $0.65 \pm 0.26$ & $0.90 \pm 0.29$ & $0.38 \pm 0.08$ & \\
\hline & $\mathrm{C}$ & $0.56 \pm 0.14$ & $0.33 \pm 0.26$ & $0.28 \pm 0.28$ & $0.51 \pm 0.33$ & $0.25 \pm 0.18$ & \\
\hline & $\mathrm{D}$ & $0.35 \pm 0.12$ & $0.44 \pm 0.46$ & $0.37 \pm 0.09$ & $0.64 \pm 0.29$ & $0.27 \pm 0.04$ & \\
\hline \multirow[t]{4}{*}{ Acceleration $(\mathrm{m} / \mathrm{s} / \mathrm{s})$} & & $\mathrm{D}>(\mathrm{AB})=\mathrm{C}$ & NS & $\mathrm{D}>(\mathrm{AB})=\mathrm{C}$ & NS & NS & NS \\
\hline & $\mathrm{AB}$ & $0.27 \pm 0.19$ & $2.87 \pm 3.06$ & $0.22 \pm 0.16$ & $1.77 \pm 1.00$ & $0.38 \pm 0.26$ & \\
\hline & $\mathrm{C}$ & $0.46 \pm 0.20$ & $5.64 \pm 3.16$ & $0.36 \pm 0.12$ & $2.66 \pm 1.42$ & $0.47 \pm 0.18$ & \\
\hline & $\mathrm{D}$ & $0.55 \pm 0.20$ & $4.12 \pm 4.1$ & $0.50 \pm 0.18$ & $3.27 \pm 1.79$ & $0.66 \pm 0.49$ & \\
\hline \multirow[t]{4}{*}{ Force $[\mathrm{N} ;(\mathrm{kg} \cdot \mathrm{m} / \mathrm{s} / \mathrm{s})$} & & NS & NS & NS & NS & NS & NS \\
\hline & $\mathrm{AB}$ & $0.14 \pm 0.11$ & $1.56 \pm 1.66$ & $0.10 \pm 0.06$ & $1.02 \pm 0.61$ & $0.22 \pm 0.16$ & \\
\hline & $\mathrm{C}$ & $0.17 \pm 0.07$ & $2.00 \pm 0.88$ & $0.14 \pm 0.04$ & $0.95 \pm 0.39$ & $0.18 \pm 0.07$ & \\
\hline & $\mathrm{D}$ & $0.22 \pm 0.09$ & $1.51 \pm 1.39$ & $0.20 \pm 0.06$ & $1.23 \pm 0.69$ & $0.25 \pm 0.20$ & \\
\hline \multirow[t]{4}{*}{ Work (J) } & & NS & NS & NS & NS & NS & NS \\
\hline & $\mathrm{AB}$ & $0.06 \pm 0.09$ & $0.16 \pm 0.12$ & $0.05 \pm 0.04$ & $0.04 \pm 0.02$ & $0.02 \pm 0.01$ & \\
\hline & $\mathrm{C}$ & $0.12 \pm 0.05$ & $0.20 \pm 0.06$ & $0.11 \pm 0.06$ & $0.09 \pm 0.04$ & $0.02 \pm 0.03$ & \\
\hline & $\mathrm{D}$ & $0.05 \pm 0.03$ & $0.15 \pm 0.07$ & $0.04 \pm 0.07$ & $0.03 \pm 0.06$ & $0.01 \pm 0.03$ & \\
\hline \multirow[t]{4}{*}{ Number of tailflips (Tf) } & & NS & NA & NS & NS & NS & NS \\
\hline & $\mathrm{AB}$ & $3.5 \pm 1.9$ & & $2.5 \pm 1.5$ & $1.8 \pm 0.9$ & $0.9 \pm 0.3$ & \\
\hline & $\mathrm{C}$ & $5.8 \pm 1.8$ & & $4.8 \pm 1.8$ & $3.6 \pm 1.0$ & $1.3 \pm 0.4$ & \\
\hline & $\mathrm{D}$ & $3.5 \pm 3.1$ & & $2.5 \pm 2.7$ & $2.0 \pm 2.0$ & $1.6 \pm 0.8$ & \\
\hline \multirow[t]{4}{*}{ Frequency $(\mathrm{Tf} / \mathrm{s})$} & & $(C=D)>A B$ & NA & $(C=D)>A B$ & $(C=D)>A B$ & NS & $\mathrm{C} 1>\mathrm{C} 2$ \\
\hline & $\mathrm{AB}$ & $3.05 \pm 1.08$ & & $6.96 \pm 1.69$ & $3.63 \pm 3.17$ & $3.33 \pm 2.59$ & $\mathrm{D} 1>\mathrm{D} 2$ \\
\hline & $\mathrm{C}$ & $4.52 \pm 1.34$ & & $10.52 \pm 4.17$ & $8.40 \pm 3.54$ & $2.12 \pm 0.91$ & \\
\hline & $\mathrm{D}$ & $3.94 \pm 1.02$ & & $10.78 \pm 1.02$ & $9.13 \pm 2.40$ & $1.65 \pm 1.94$ & \\
\hline \multirow[t]{4}{*}{ Distance/Weight (m/kg) } & & NS & NS & NS & NA & NA & NA \\
\hline & $\mathrm{AB}$ & $0.52 \pm 0.46$ & $0.10 \pm 0.03$ & $0.41 \pm 0.50$ & & & \\
\hline & $\mathrm{C}$ & $1.67 \pm 0.16$ & $0.17 \pm 0.03$ & $1.52 \pm 0.11$ & & & \\
\hline & $\mathrm{D}$ & $0.84 \pm 0.72$ & $0.21 \pm 0.07$ & $0.61 \pm 0.72$ & & & \\
\hline \multirow[t]{4}{*}{$\begin{array}{l}\text { Distance/Weight/Tailflip } \\
\qquad(\mathrm{m} / \mathrm{kg} / \mathrm{Tf})\end{array}$} & & $\mathrm{C}>(\mathrm{AB}=\mathrm{D})$ & NS & $\mathrm{C}>(\mathrm{AB}=\mathrm{D})$ & NA & NA & NA \\
\hline & $\mathrm{AB}$ & $0.14 \pm 0.07$ & $0.10 \pm 0.03$ & $0.12 \pm 0.05$ & & & \\
\hline & $\mathrm{C}$ & $0.41 \pm 0.09$ & $0.17 \pm 0.03$ & $0.38 \pm 0.06$ & & & \\
\hline & $\mathrm{D}$ & $0.23 \pm 0.07$ & $0.21 \pm 0.07$ & $0.19 \pm 0.05$ & & & \\
\hline \multirow[t]{4}{*}{ Distance/Bodylength } & & $\mathrm{C}>(\mathrm{AB}=\mathrm{D})$ & NS & $\mathrm{C}>(\mathrm{AB}=\mathrm{D})$ & NA & NA & NA \\
\hline & $\mathrm{AB}$ & $3.5 \pm 1.9$ & $0.13 \pm 0.03$ & $3.1 \pm 1.6$ & & & \\
\hline & $\mathrm{C}$ & $5.8 \pm 1.8$ & $0.10 \pm 0.02$ & $5.4 \pm 1.7$ & & & \\
\hline & $\mathrm{D}$ & $3.5 \pm 3.1$ & $0.15 \pm 0.03$ & $3.1 \pm 2.8$ & & & \\
\hline
\end{tabular}

A, B , C , and D represent the four molt stages. Mean \pm SD of all components analyzed for three molt stages. Significant differences are indicated in boxes at the top of each column. Stages equated with those in the parentheses are not significantly different from them.

$\mathrm{AB}$, results of experiments with stages $\mathrm{A}$ and $\mathrm{B}$ were pooled due to only 4 animals that tailflipped.

SS1, first half of the subsequent swimming distance; SS2, second half of the subsequent swimming distance.

SS1 versus SS2 compares the component in the two halves of the subsequent swimming distance.

NA, not analyzed due to the experimental design (see methods).

NS, no significant difference. 
$\mathrm{A}$

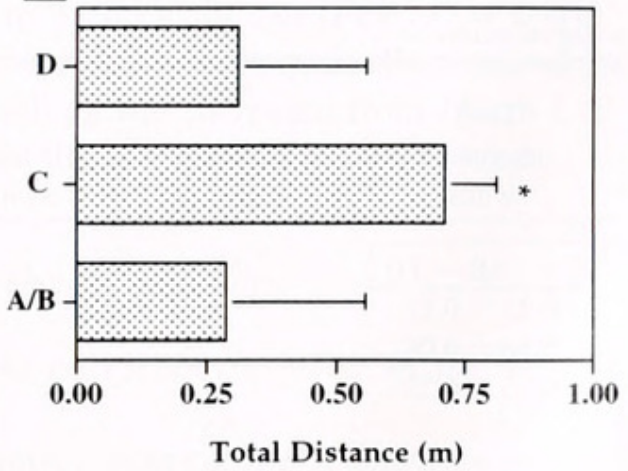

B

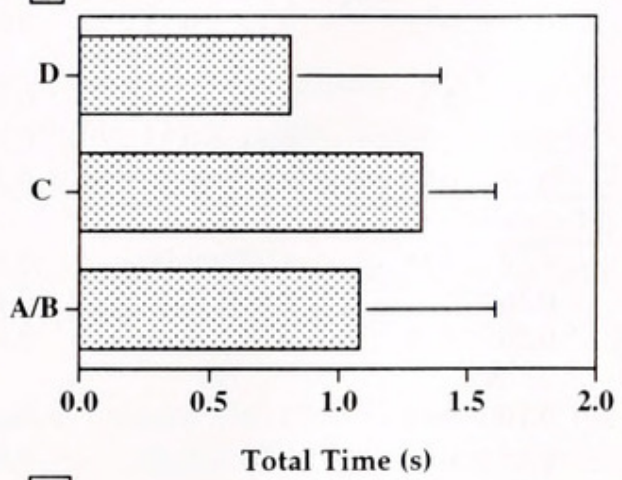

C

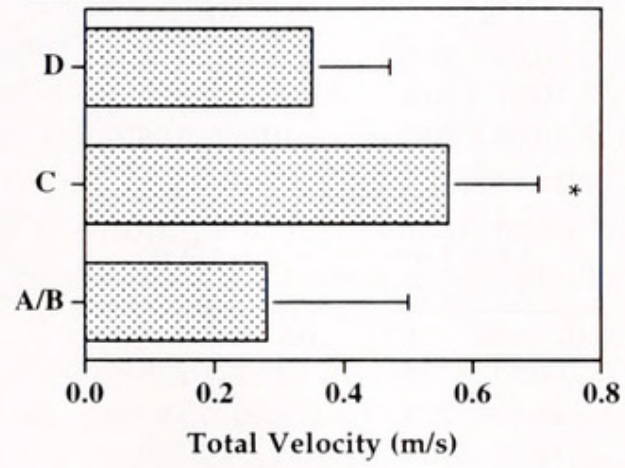

D

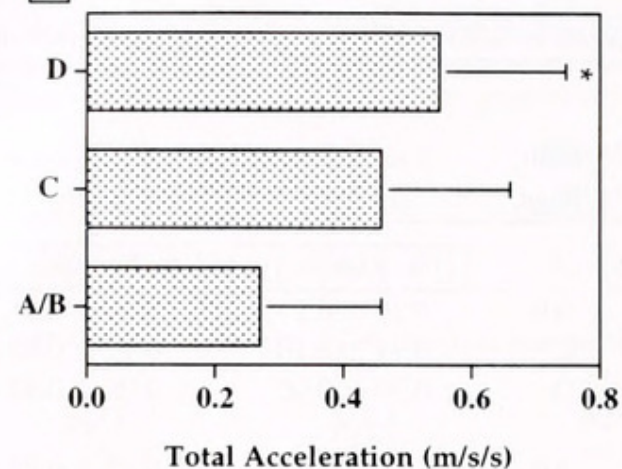

E

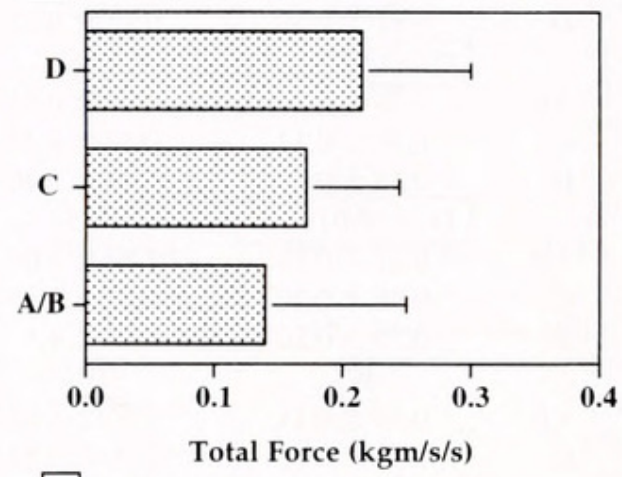

F

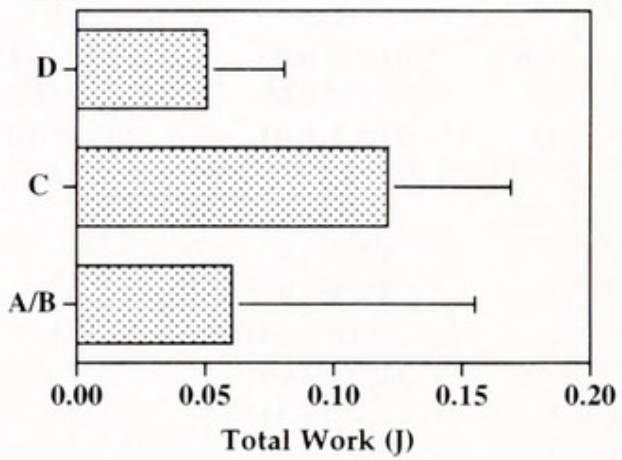

Figure 3. Parameters of the total escape response (initial power swim plus subsequent swims) for adult lobsters in all three molt stages. An asterisk $\left(^{*}\right)$ indicates significant differences. (A) Distance traveled in meters (m). (B) Time spent escaping in seconds (s). (C) Velocity of tailflips in meters/second ( $\mathrm{m} / \mathrm{s}$ ). (D) Acceleration in meters $/$ second/second $(\mathrm{m} / \mathrm{s} / \mathrm{s})$. (E) Force of tailflips in newtons $(\mathrm{kg} \cdot \mathrm{m} / \mathrm{s} / \mathrm{s}$ ). (F) Work produced (force $\times$ distance) is measured in joules $(\mathbf{J})$.

$\left(\mathrm{KW}, \chi^{2}=4.98, P=0.083\right.$ and $\chi^{2}=2.15, P=0.16$; Fig. 3E and $3 \mathrm{~F}$, respectively).

Although the total number of tailflips and the total time were not significantly different $\left(\mathrm{KW}, \chi^{2}=4.20, P=\right.$ 0.123 and $\chi^{2}=2.58, P=0.275$, respectively), swim frequency was significantly higher for intermolt and premolt lobsters, with stage $\mathrm{C}$ and $\mathrm{D}$ lobsters performing more tailflips per second than $\mathrm{AB}$ animals $\left(\mathrm{KW}, \chi^{2}=6.93, P=\right.$ 0.048; Fig. 4A). Distance traveled per lobster weight per tailflip was greater for intermolt (stage $\mathrm{C}$ ) animals than for the other molt stages $\left(\mathrm{C}>(\mathrm{AB}=\mathrm{D}) ; \mathrm{KW}, \chi^{2}=5.98\right.$, $P=0.046$, Fig. 4D), and distance traveled per bodylength was also greater for intermolt animals than for the other molt stages $\left(\right.$ stages $\left(\mathrm{C}>(\mathrm{AB}=\mathrm{D}) ; \mathrm{KW}, \chi^{2}=5.36, P=\right.$ 0.047, Fig. 4F).

\section{Initial power swim}

Except for distance traveled, none of the parameters were significantly different for the three molt stages at $P \leq 0.05$, no doubt because of the large variability among the animals that exhibited an escape response. However, trends in the tests suggest that intermolt and premolt lobsters executed a faster, more accelerating, and more forceful power swim than postmolt animals $(0.05 \leq P \leq 0.10$; KW $)$.

\section{Subsequent swims \\ a. Entire subsequent swim}

Of the original 15 animals that responded to the stimulus with escape swimming, only 12 executed subsequent swims. Of these, 3 were postmolts (stages A and B), 5 were intermolts (stage C), and 4 were premolts (stage D). The following parameters were statistically different: the fre- 
A

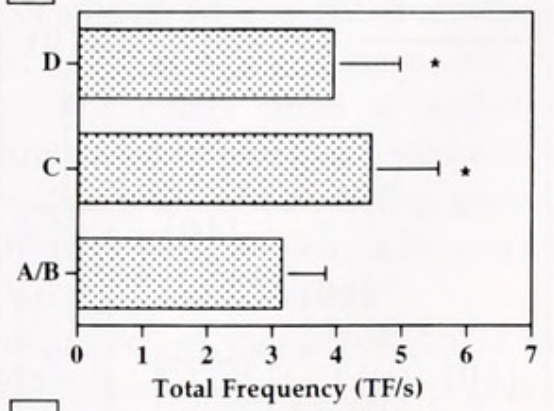

$D$

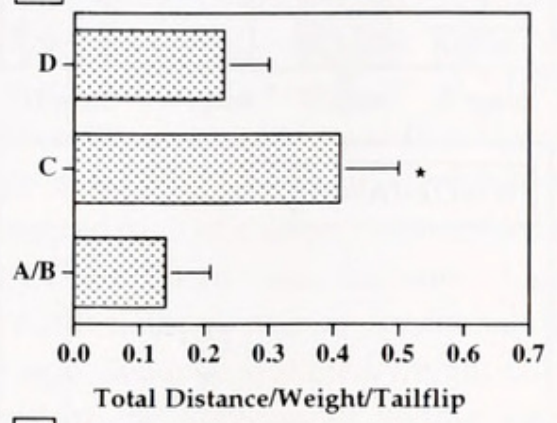

$F$

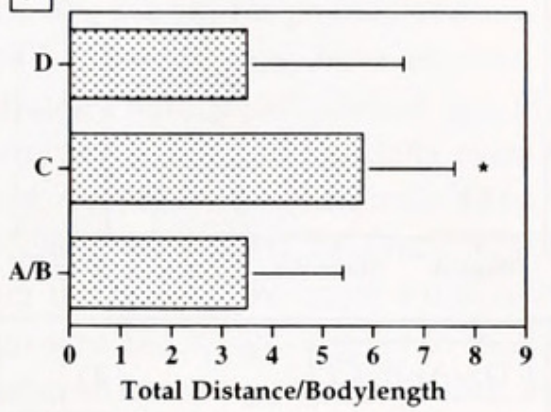

B

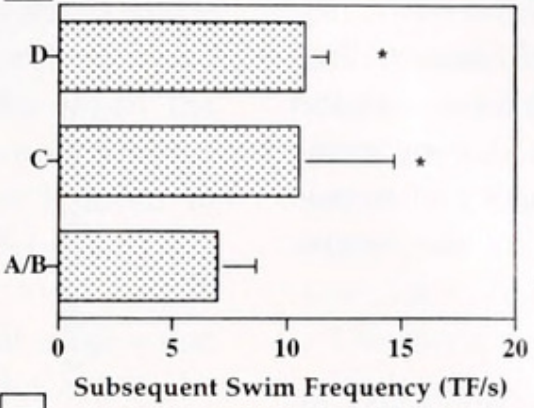

E

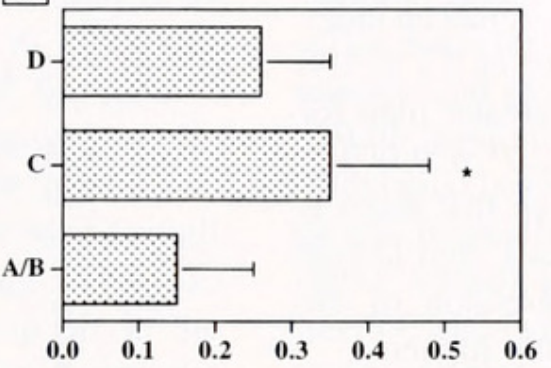

Subsequent Swim Distance/Weight/Tailflip

G

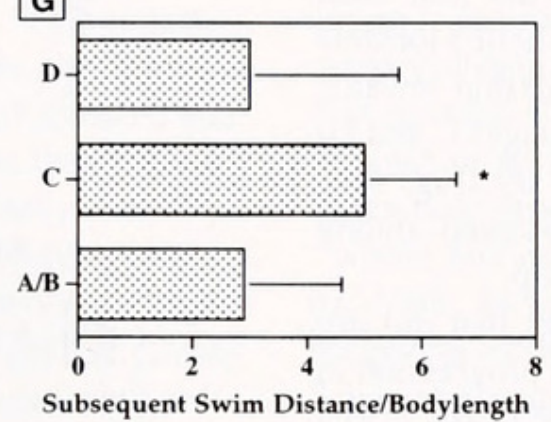

C

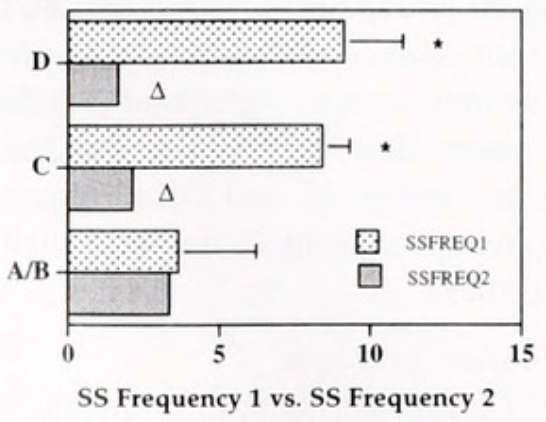

Figure 4. Mean frequency of tailflips ( $\mathrm{Tf} / \mathrm{s})$ for adult lobsters for (A) total swim sequence; (B) the total subsequent swims frequency, and $(\mathrm{C})$ the subsequent swims of both the first and second halves. Mean distance per weight per tailflip (m/kg/Tf) for the total swim sequence (D) and for the total subsequent swims - that is, minus the power stroke (E). Mean distance per bodylength for total distance of swim sequence per bodylength (F) and for the total subsequent swims distance per bodylength (G). Stage AB $(n=3)$, stage $\mathrm{C}(n=5)$, and stage $\mathrm{D}(n=4)$. An asterisk $(*)$ indicates significant differences among the molt stages; a triangle $(\triangle)$ indicates significant differences between the two halves of the subsequent swims.

quency of swimming was higher for stages $\mathrm{C}$ and $\mathrm{D}(\mathrm{KW}$ $\chi^{2}=7.92, P=0.037$; Fig. 4B); the distance swum per weight per tailflip was higher in intermolt (stage $\mathrm{C}$ ) animals $\left(\mathrm{KW}, \chi^{2}=8.01, P=0.028\right.$, Fig. $\left.4 \mathrm{E}\right)$; and distance per bodylength was greater for intermolt (Stage $\mathrm{C}$ ) animals than for the other molt stages (KW, $\chi^{2}=6.46, P=0.046$, Fig. $3 G)$.

\section{b. Comparisons of SS1 and SS2}

As in the previous study (Cromarty et al., 1991), the total distance traveled by each animal during the entire subsequent escape swims was divided in half and then the swimming parameters were compared for each of the two halves across the molt stages and between the two halves of the swimming distance within each molt stage. SS1 $=$ the first half of the distance; SS2 = the second half.

Comparison of SS1 across molt stages. In the first half of the subsequent swims, stage $\mathrm{C}$ and $\mathrm{D}$ lobsters swam at a higher frequency than stages $\mathrm{A}$ and B (MANOVA, $F(1$, $9)=23.18, P=0.014$; Fig. 4C).

Comparison of SS2 across molt stages. No significant differences were found in any of the parameters for the second half of the subsequent swims among the molt stages (Table 2).

Comparison of SS1 and SS2 (SS, vs. $S_{2}$ ) within each molt stage. For the following parameters-subsequent swimming distance, duration, velocity, acceleration, force, work output, number of tailflips-no significant differences were found between the two halves of the subsequent swims within each molt stage. There was a significant drop-off in the frequency of swims between the first to the second halves of the subsequent swims for hard-shelled (stages C and D), while no differences between SS1 and SS2 were 
observed for soft-shelled (stages A and B) lobsters (MANOVA $F(1,9), P \leq 0.003$; Fig. $4 \mathrm{C}$ ).

Comparison of SS1 and SS2 across molt stages. Frequency of swimming was significantly different among the three molt stages (MANOVA, $P \leq 0.026$ ). Among hardshelled lobsters (stages $C$ and D), the frequency of swimming was greatly reduced in the latter half of the escape swims (Fig. 4C).

\section{Post-threat behavior}

There was a gradual increase in the aggression index of all lobsters in the experiment, such that stage A had an index value of $0.3 \pm 0.5$, while stage $D$ had a value of $2.2 \pm 1.4$. The values for stage $\mathrm{D}$ were significantly greater than for molt stages A, B, and C (ANOVA $F(3,39), P \leq 0.0012$; Fig. 5A). This is especially interesting given that stage $\mathrm{B}$ animals were significantly larger than stages $C$ and D (see section A above), yet the post-threat aggression of the smaller hard-shelled lobsters was significantly higher.

Among the animals that tailflipped, there were significant differences in the aggression index among the four molt stages (ANOVA $F(3,11), P \leq 0.02)$ : soft-shelled lobsters (stages A and B) had very low or zero aggression towards the stimulus, whereas hard-shelled lobsters (stages C and D) had an overall aggression index of $1.4 \pm .09$ (Fig. 5B). Importantly, no weight differences were observed among the molt stages for the animals that did tailflip.

When the post-threat behaviors of lobsters that did not tailflip were compared over the molt stages, a progression in the index was observed: starting with a value of $0.4 \pm 0.5$ for stage A lobsters, the index gradually increased until the index for stage $\mathrm{D}$ animals was $3.3 \pm 0.5$. Stage D lobsters had a significantly higher aggression index than molt stages A, B, and C (ANOVA $F(3,21), P \leq 0.0001$; Fig. 5C). Although the soft-shelled animals were significantly larger than the hard-shelled ones (see section A), the smaller hard-shelled lobsters were more aggressive in their postthreat behaviors.

\section{Discussion}

In this study, we show that, like juveniles, adult male lobsters display significant molt-related differences in escape behavior. However, the escape behavior of adults, unlike that of juveniles (weight less than $100 \mathrm{~g}$ ), is also influenced by physical factors.

Thus, we have found that among animals that did not respond to a threat with an escape response, soft-shelled adults weighed significantly more than hard-shelled adults. This suggests that an animal's weight begins to modify the molt-dependent swimming response to threat.

In our earlier experiments, all juvenile animals (both soft and hard-shelled; $\pm 14 \mathrm{~g}$ ) responded to a stimulus threat with escape swimming (Cromarty et al., 1991). No adults responded to the same stimulus that induced 14-g juveniles
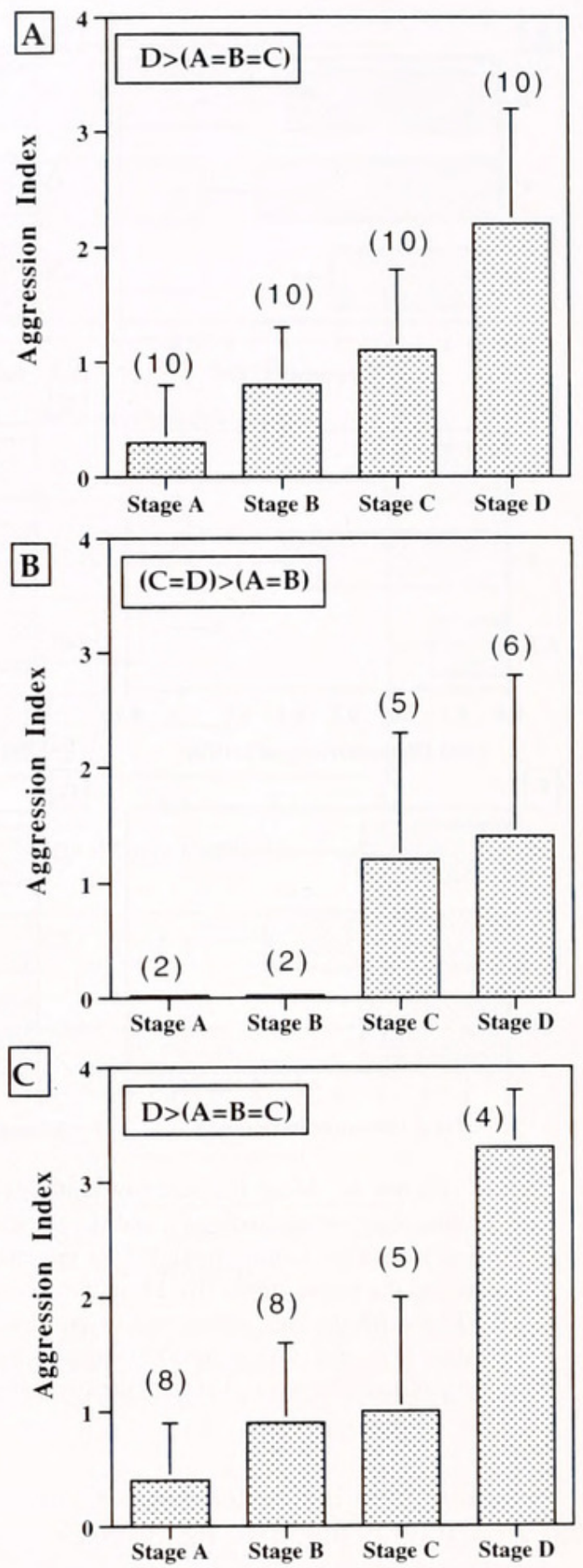

Figure 5. Mean aggression index for post-threat behavior of adult lobsters for (A) all lobsters regardless of tailflipping; (B) lobsters that did tailflip; and (C) lobsters that did not tailflip. The numbers in parentheses represent the number of individuals in each molt stage; the statistical differences are displayed in a box in the upper left-hand corner of each graph.

to swim. Indeed, adults failed to respond to a number of other stimuli (such as air bubbles, water injection, larger conspecifics) that were presented to them and ultimately responded only to a heavy weight (PVC tubing filled with pebbles and weighing $1.45 \mathrm{~kg}$ ) dropped suddenly in their paths.

There seems to be an inverse relationship between 
the probability of eliciting an escape response and the weight of an animal: $14-\mathrm{g}$ juveniles tailflipped with a $100 \%$ probability; $450-\mathrm{g}$ adults tailflipped with a probability of $50 \%$, and $600 \mathrm{-g}$ adults failed to tailflip even when the stimulus size was doubled. Other workers have shown that lobsters weighing more than $600 \mathrm{~g}$ could be induced to tailflip only if their claws were autotomized (Lang et al., 1977), as we also have observed.

It appears, therefore, that the effects of molt stage- that is, an animal's physiological condition, characterized by the hardness of its shell (Aiken, 1973; 1980), the flaccidity of its muscles (Passano, 1960), and the titers of its hormones (Stevenson et al., 1979; Fadool et al., 1989; Snyder and Chang, 1991a, b) — begin to be modified by size and weight.

That size and weight begin to modulate the molt-determined characteristics of escape swimming can be seen if all our findings are taken into account. Among adults, as among juveniles, there was a significant drop off in the frequency and distance traveled/weight/tailflip during the second half of the subsequent swims for premolt hardshelled animals, but not for postmolt animals. This suggests that escape swimming may have evolved as the primary survival strategy among soft-shelled juvenile animals, and that this strategy is retained in adults even as they become heavier; however, fewer large animals were likely to tailflip, perhaps because swimming becomes less energy-efficient (the heavier the animal, the more work is involved).

Although size and weight appear to modulate the effects of molt stage on escape swimming, with larger adult softshelled animals not tailflipping, an inverse relationship to weight became apparent in the post-threat behaviors of our experimental animals. Regardless of whether the animals had tailflipped-and even when weight was taken into account - the indices of aggression of the post-threat behaviors increased incrementally from stages A and B (the largest animals) to stages $\mathrm{C}$ and $\mathrm{D}$ (the smallest animals). Weight and size appears to be of secondary importance in post-threat aggression; indeed, changes in aggression over the molt stages were the deciding factor, with the lobsters responding to a threat in accordance with the expected molt-related changes in aggressive behaviors (Tamm and Cobb, 1978). Undue significance should not be given to the inverse relationship of weight and size on aggression in general, however. In confrontations between lobsters in the same molt stage, the size of an opponent significantly affected the outcome of a bout (Scrivener, 1971; Mello et al., 1999; Bolingbroke and Kass-Simon, 2000).

Overall, we found that among juveniles, soft-shelled animals were better swimmers than their hard-shelled counterparts, but among adults, hard-shelled premolt and intermolt lobsters were the best swimmers. Thus juveniles of stage B outperformed stage C and D animals in the following parameters: distance traveled, number of tailflips produced, distance/tailflip, time spent swimming, and velocity
(Cromarty et al., 1991). In contrast, among adults, hardshelled premolt and intermolt animals outperformed softshelled animals in distance traveled, velocity, acceleration, frequency and distance traveled/lobster weight/tailflip. This would suggest that molt stage is the predominant determinant of the characteristics of escape behavior in smaller animals, while other physical factors such as weight and claw size may begin to dominate among adults.

The physiological bases for the differences in adult and juvenile escape behavior over the molt cycle are likely to be manifold and varied. In addition to probable differences within the central nervous system, differences in endocrine, sensory, and motor systems are certain to exist.

With regard to sensory systems (Watson, 1992), synaptic modulation has been described for mechanoreceptors (Pasztor and Bush, 1987) and stretch receptors (El Manira et al., 1991). Studies by Coulter (1988) indicate that lobsters in stages $C$ and $D$ responded (with a meral spread) at different speeds to the presentation of an expanding black disc. Increases in lobster size have been correlated with a decrease in the speed of an action potential traveling from the sensory system to the central nerve cord (Lang et al., 1977). It is possible that juvenile and adult lobsters perceive and respond to stimuli differently due to inherent age-related differences in sensory functioning.

Other factors such as central (Kravitz et al., 1984; Kravitz, 1988; Yeh et al., 1996, 1997; Hörner et al., 1997) and peripheral modulations (Kravitz et al., 1980; Kravitz, 1990; Schwanke et al., 1990) are likely to affect molt-cycle behavior. We have recently found that 20-hydroxyecdysone (20-HE), the active steroid regulating the molt, also alters the neuromuscular properties of the claw-opener and phasic flexor systems in intermolt animals (Cromarty, 1995; Cromarty and Kass-Simon, 1998), in a way that is consistent with molt-determined behavioral differences (Tamm and Cobb, 1978; Cromarty et al., 1991). Our findings are consistent with the rise in the blood titer of 20-HE (Snyder and Chang, 1991a, b) when lobster aggression is beginning to peak. In our 20-HE experiments we found that 20-HE increases the size of the excitatory junctional potential (EJP) in the claw opener muscle, which is used in threat displays, and decreases the EJP amplitude in the abdominal phasic flexor, which is used in escape behavior. In crayfish, Cooper and Ruffner (1998) have found that EJP amplitude in the opener muscle of the walking legs is reduced; this keeps the dactyl from splaying and allows the animal to stand tall, as has been observed in dominant lobster displays (for recent review on modulation of aggressive behavior, see Kravitz, 2000). The effects of 20-HE on these above-mentioned tissues are consistent with the functions attributed to them during agonistic behavior. Our recent studies also show that when 20-HE is directly injected into the lobsters' hemolymph, aggressive behavior increases dramatically during agonistic encounters, although the probability of eliciting 
escape swimming is unaltered (Bolingbroke and Kass-Simon, 2000).

The sexual status of an American lobster may also alter its use of escape behavior. Intermolt gravid females that are presented with a startle stimulus do not tailflip, whereas intermolt males and non-gravid females tailflip readily (Cromarty et al., 1998); gravidity did not appear to affect escape behavior during a confrontation, but caused an increase in aggressive tail flipping (Mello et al., 1999). It remains to be seen whether neuromuscular properties are modulated to reflect these sex-related behavioral differences.

Among juveniles, we have found that EJPs in the distal region of the muscle in soft-shelled stage $B$ animals are larger and have a greater amplitude-duration integral than those of hard-shelled D stage animals (Cromarty et al., 1995). Earlier studies by Schwanke et al. (1990) also found molt-related differences in the dactyl opener muscle. These findings correspond with the fact that stage B juveniles swim greater distances by covering more distance in each swim than do hard-shelled (stage C and D) juveniles. Further, although EJPs continue to be produced at frequencies up to $6 \mathrm{~Hz}$ in stage $\mathrm{A}$ and $\mathrm{B}$ juveniles, they begin to fail at $4 \mathrm{~Hz}$ in stage $\mathrm{C}$ and $\mathrm{D}$ animals. This also correlates with the fact that stage $\mathrm{B}$ juveniles swim longer and cover more ground, and that stage $\mathrm{A}$ animals are able to sustain swimming longer and at a higher frequency than stage $\mathrm{C}$ or $\mathrm{D}$ animals (Cromarty et al., 1991; Cromarty et al., 1995).

Among adults, EJPs were found to fail at $4 \mathrm{~Hz}$ in softshelled postmolts but continued to $6 \mathrm{~Hz}$ in intermolt and premolt animals (Cromarty and Kass-Simon, 1994). As in juveniles, in adults, EJPs were largest and longest lasting in the distal region of soft-shelled postmolts. We have also found that EJPs in the proximal region of the abdominal phasic flexor muscles, the anchorage or insertion region of the contracting muscle, are significantly greater in adult $\mathrm{C}$ and D stages than in juvenile C and D stages (Cromarty and Kass-Simon, 1994). This coincides with their greater swimming ability and supports our present finding that escape swimming is used less as the animal grows, although hardshelled animals retain it longer than soft-shelled animals do. This might be because escape swimming would be less effective in large soft-shelled animals-not only because of the large mass that would need to be propelled by the still-flaccid muscles, but also because the large transmitter output required by these muscles might not be sustainable for long periods at higher frequencies.

\section{Acknowledgments}

The authors thank Bill MacElroy for allowing us to collect animals while he was fishing offshore, and Tom Angell of the Rhode Island Department of Environmental Management for supplying us with additional lobsters.
Thanks to Dr. Mike Clancy and Kathy Castro for help in lobster collection and maintenance. Drs. Stanley Cobb and Frank Heppner kindly provided laboratory space and equipment. We also thank Malia Schwartz for critiquing an earlier draft of the manuscript. This research was supported by a Whitehall Foundation grant to G.K-S, Grant-in Aid of Research from Sigma Xi and Lerner Gray Grants for Marine Research to S.I.C.

\section{Literature Cited}

Aiken, D. E. 1973. Proecdysis, setal development, and molt prediction in the American lobster (Homarus americanus). J. Fish. Res. Board Can. 30: 1334-1337.

Aiken, D. E. 1980. Molting and growth. Pp. 91-163 in The Biology and Management of Lobsters. vol. 1, J. S. Cobb and B. F. Phillips, eds. Academic Press, New York.

Atema, J., and J. S. Cobb. 1980. Social behavior. Pp. 409-450 in The Biology and Management of Lobsters, Vol. 1, J. S. Cobb and B. F. Phillips, eds. Academic Press, New York.

Atema, J., and R. Voigt. 1995. Behavior and sensory biology. Pp. 313-348 in The Biology of the Lobster, Homarus americanus. J. Factor, ed. Academic Press, New York.

Batchelor, G. K. 1967. An Introduction to Fluid Dynamics. Cambridge University Press, London.

Bolingbroke, M. B., and G. Kass-Simon. 2000. Increased aggressiveness in female American lobsters caused by 20-hydroxyecdysone. Soc. Neurosci. Abstr. 26: 368.5.

Cooper, R. L., and M. E. Ruffner. 1998. Depression of synaptic efficacy at intermolt in crayfish neuromuscular junctions by 20 -hydroxyecdysone, a molting hormone. J. Neurophysiol. 79: 1931-1941.

Coulter, D. 1983. Analysis of a visually-evoked aggressive display in the American lobster, Homarus americanus. MS Thesis, University of Rhode Island, Kingston, RI.

Cowan, D. C., and J. Atema. 1990. Moult staggering and serial monogamy in American lobsters, Homarus americanus. Anim. Behav. 39: $1199-1206$.

Cromarty, S. I. 1995. Neuroethology of the escape behavior in the American lobster, Homarus americanus, over the molt cycle. Ph.D. dissertation, University of Rhode Island, Kingston, RI.

Cromarty, S. I., and G. Kass-Simon. 1994. Plasticity of the non-giant phasic flexor neuromuscular junctions in the adult American lobster, Homarus americanus, over the molt cycle. Soc. Neurosc. Abstr. 20: 331.

Cromarty, S. I., and G. Kass-Simon. 1998. Differential effects of a molting hormone, 20-hydroxyecdysone, on the neuromuscular junctions of the claw opener and abdominal flexor muscles of the American lobster. Comp. Biochem. Physiol. 120(2): 289-300.

Cromarty, S. I., J. S. Cobb, and G. Kass-Simon. 1991. Behavioral analysis of the escape response in juvenile American lobsters, Homarus americanus over the molt cycle. J. Exp. Biol. 158: 565-581.

Cromarty, S. I., J. S. Cobb, and G. Kass-Simon. 1995. Adult and juvenile lobsters (Homarus americamus) differ markedly in the neuromuscular physiology and behavior of the escape response over the molt cycle. Soc. Neurosc. Abstr. 21: 72.12.

Cromarty, S. I., J. Mello, and G. Kass-Simon. 1998. Comparative analysis of escape behavior in male, and gravid and non-gravid, female lobsters. Biol. Bull. 194: 63-71.

Cromarty, S. I., J. Mello, and G. Kass-Simon. 1999. Time in residence affects escape and agonistic behavior in adult male American lobsters. Biol. Bull. 196: 105-112

Daniel, T. L., and E. Meyhöfer. 1989. Size limits in escape locomotion of caridean shrimp. J. Exp. Biol. 143: 245-265. 
EI Manira, A., C. Rossi-Durand, and F. Clarac. 1991. Serotonin and proctolin modulate the response of a stretch receptor in crayfish. Brain Res. 541: 157-162.

Fadool, D. A., P. R. Brown, J. S. Cobb, and G. Kass-Simon. 1989. HPLC analysis of lobster haemolymph over the molt cycle. Comp Biochem. Physiol. 93C: 225-230.

Figler, M. H., H. V. S. Peeke, and E. S. Chang. 1997. Maternal aggression in American lobsters (Homarus americanus Milne Ed wards): shelter-related encounters against non-maternal conspecifics. Mar. Freshw. Behav. Physiol. 30: 267-274.

Figler, M. H., H. V. S. Peeke, and E. S. Chang. 1998. Shelter-related aggression between adult male conspecific intruders and resident maternal American lobsters (Homarus americanus) with eggs at different stages of embryogenesis. Mar. Freshw. Behav. Physiol. 31: 151-166.

Huber, R., and E. A. Kravitz. 1995. A quantitative analysis of agonistic behavior in juvenile American lobsters (Homarus americanus L.). Brain. Behav. Evol. 46: 72-83

Hörner, M., W. Weiger, D. H. Edwards, and E. A. Kravitz. 1997. Excitation of identified serotonergic neurons by escape command neurons in lobsters. J. Exp. Biol. 200: 2017-2033.

Karnofsky, E. B., and H. J. Price. 1989. Dominance, territoriality and mating in the lobster, Homarus americanus: a mesocosm study. Mar. Behav. Physiol. 15: 101-121.

Kleinholz, L. H., and R. Keller. 1979. Endocrine regulation in Crustacea. Pp. 159-214 in Hormones and Evolution. J. W. Barrington, ed Academic Press, New York

Knowles, F. G. W., and D. B. Carlisle. 1956. Endocrine control in the Crustacea. Biol. Revs. Cambr. Philos. Soc. 31: 396-473.

Krasne, F. B., and J. J. Wine. 1975. Extrinsic modulation of crayfish escape behaviour. J. Exp. Biol. 63: 433-450

Kravitz, E. A. 1988. Hormonal control of behavior: amines and the biasing of behavioral output in lobsters. Science 241: 1775-1781

Kravitz, E. A. 1990. Hormonal control of behavior: amines as gainsetting elements that bias behavioral output in lobsters. Am. Zool. 30: $595-608$

Kravitz, E. A. 2000. Serotonin and aggression: insights gained from a lobster model system and speculations on the role of amine neurons in a complex behavior like aggression. J. Comp. Physiol. A. 186: 221238

Kravitz, E. A., S. Glusman, R. M. Harris-Warrick, M. S. Livingstone, T. Schwarz, and M. F. Goy. 1980. Amines and a peptide as neurohormones in lobster: actions on neuromuscular preparations and preliminary behavioral studies. J. Exp. Biol. 89: 159-175.

Kravitz, E. A., B. Beltz, S. Glusman, M. Goy, R. Harris-Warrick, M. Johnston, M. Livingstone, and T. Schwarz. 1984. The well-modulated lobster: the roles of serotonin, octopamine and proctolin in the lobster nervous system. Pestic. Biochem. Physiol. 22: 133-147.

Lang, F., C. K. Govind, W. J. Costello, and S. I. Greene. 1977 Developmental neuroethology: changes in escape and defensive behavior during growth of the lobster. Science 197: 682-684.

Lnenicka, G. A., and Y. Zhao. 1991. Seasonal differences in the physiology and morphology of crayfish motor terminals. J. Neurobiol. 22: $561-569$

Mello, J., S. I. Cromarty, and G. Kass-Simon. 1999. Increased aggressiveness in gravid female American lobsters, Homarus americanus. Aggressive. Behav. 25: 451-472.
Nauen, J. C., and R. E. Shadwick. 1999. The scaling of acceleratory aquatic locomotion: body size and tail-flip performance of the California spiny lobster Panulirus interruptus. J. Exp. Biol. 202: 3181-3193.

O'Neill, D. J., and J. S. Cobb. 1979. Some factors influencing the outcome of shelter competition in lobsters (Homarus americanus). Mar. Behav. Physiol. 6: $33-45$

Passano, L. M. 1960. Molting and its control. Pp. 473-536 in The Physiology of Crustacea. Vol. 1. T. H. Waterman, ed. Academic Press. New York.

Pasztor, V. M., and B. M. H. Bush. 1987. Peripheral modulation of mechanosensitivity in primary afferent neurons. Nature 326: 793-795.

Peeke, H. V. S., M. H. Figler, and E. S. Chang. 1998. Sex differences and prior resident effects in shelter competition in juvenile lobsters, Homarus americanus Milne Edwards. J. Exp. Mar. Biol. Ecol. 229: $149-156$.

Quackenbush, L. S. 1986. Crustacean endocrinology, a review. Can. J. Fish. Aquat. Sci. 43: 2271-2282

Schwanke, M. L., J. S. Cobb, and G. Kass-Simon. 1990. Synaptic plasticity and humoral modulation of neuromuscular transmission in the lobster claw opener during the molt cycle. Comp. Biochem. Physiol. 97C: $143-149$

Scrivener, J. C. E. 1971. Agonistic behavior of the American lobster, Homarus americanus (Milne-Edwards), Fish. Res. Board Can., Tech. Report. 235: 1-128.

Snyder, M. J., and E. S. Chang. 1991a. Ecdysteroids in relation to the molt cycle of the American lobster, Homarus americanus. I. Hemolymph titers and metabolites. Gen. Comp. Endocrinol. 81: 113-145.

Snyder, M. J., and E. S. Chang. 1991b. Ecdysteroids in relation to the molt cycle of the American lobster, Homarus americanus. II. Excretion of metabolites. Gen. Comp. Endocrinol. 83: 118-131

SPSS Inc. 1988. SPSS User's Guide. SPSS Inc., Chicago.

Steger, R., and R. L. Caldwell. 1983. Intraspecific deception by bluffing: a defense strategy of newly moulted stomatopods. Science 221: $79-81$

Stevenson, J. R., P. W. Armstrong, E. S. Chang, and J. D. O'Connor. 1979. Ecdysone titers during the molt cycle of the crayfish $\mathrm{Or}$ conectes sanborni. Gen. Comp. Endocrinol. 39: 20-25.

Tamm, G. R., and J. S. Cobb. 1978. Behavior and the crustacean molt cycle: changes in aggression of Homarus americanus. Science 200: $79-81$

Watson, A. H. D. 1992. Presynaptic modulation of sensory afferents in the invertebrate and vertebrate nervous system. Comp. Biochem. Physiol. 103A: 227-239

Wine, J. J., and F. B. Krasne. 1972. The organization of escape behavior in the crayfish. J. Exp. Biol. 56: 1-18.

Wine, J. J., and F. B. Krasne. 1982. The cellular organization of crayfish escape behavior. Pp. 241-292 in The Biology of Crustacean Neurobiology: Structure and Function, Vol. 3, D. E. Bliss, ed. Academic Press, New York

Yeh, S. R., R. A. Fricke, and D. H. Edwards. 1996. The effect of social experience on serotonergic modulation of the escape circuit of crayfish. Science 271: 366-369

Yeh, S. R., B. E. Musolf, and D. H. Edwards. 1997. Neuronal adaptations to changes in the social dominance status of the crayfish. J. Neurosci. 17: 697-708 


\section{$2 \mathrm{BHL}$ Biodiversity Heritage Library}

Cromarty, S I, Mello, J, and Kass-Simon, G. 2000. "Molt-related and size-dependent differences in the escape response and post-threat behavior of the American lobster, Homarus americanus." The Biological bulletin 199, 265-277. https://doi.org/10.2307/1543183.

View This Item Online: https://www.biodiversitylibrary.org/item/17162

DOI: https://doi.org/10.2307/1543183

Permalink: https://www.biodiversitylibrary.org/partpdf/10577

\section{Holding Institution}

MBLWHOI Library

\section{Sponsored by}

MBLWHOI Library

\section{Copyright \& Reuse}

Copyright Status: In copyright. Digitized with the permission of the rights holder.

License: http://creativecommons.org/licenses/by-nc-sa/3.0/

Rights: https://biodiversitylibrary.org/permissions

This document was created from content at the Biodiversity Heritage Library, the world's largest open access digital library for biodiversity literature and archives. Visit BHL at https://www.biodiversitylibrary.org. 